\title{
Contextualism of architecture in Warmia and Mazury
}

\section{Kontekstualizm architektury Warmii i Mazur}

\begin{abstract}
When discussing the issue of the context of architecture, it is important to pay attention to the possibilities of impact and connections between the building and is surroundings. Some buildings are connected with the area in terms of functionality, others in terms of history and others in terms of nature. Different styles of finishes, materials or forms directly affect the dialogue between the architecture and nature. This issue is worth discussing in more detail in order to understand the reasons why the architecture of Warmia and Mazury stands out among other regions of Poland. What makes its unique finishes co-create some of the most picturesque landscapes in Poland?
\end{abstract}

Keywords: context, region, Mazury, Warmia, dialogue

\section{Streszczenie}

Omawiając zagadnienie kontekstu architektury, należy zwrócić uwagę na możliwości oddziaływań i powiązań budynku z otoczeniem. Niektóre budynki są związane z terenem pod względem funkcjonalnym, inne historycznym, a inne przyrodniczym. Różne style wykończeń, materiały czy formy oddziałują bezpośrednio na dialog architektury z naturą. Zagadnieniu temu warto się bliżej przyjrzeć w celu zrozumienia, dlaczego akurat na obszarze Warmii i Mazur architektura wyróżnia się na tle innych regionów polski. Co sprawia, że jej niepowtarzalne wykończenia współtworzą jedne z najbardziej malowniczych krajobrazów w Polsce?

Słowa kluczowe: kontekst, region, Mazury, Warmia, dialog 


\section{INTRODUCTION}

\subsection{AIM, SCOPE, METHOD}

The aim of this research is to determine the role of dialogue between the historical, cultural and natural context and the archetype of Warmia and Mazury. The time frames of these analyses cover the period related to construction, and consequently, to land settlement, from the Teutonic times on the Polish lands to the present day (Jasiński, 1978: 324). This is justified by the roots of the archetype, i.e. the ways of construction and the appearance of buildings which were influenced by numerous cultures located in this area over the centuries.

The research method consists mainly in the study and analysis of regional architecture in situ. The tools of critical analysis make it possible to study the direct context of architecture and the place to which it belongs, using numerous literature and internet sources. The clarifying aspect of the issue of context is the buildings and their surroundings, which are mainly located near the town of Olsztynek. There is an open-air museum of local folk architecture, which gives the opportunity to experience the reconstructed traditional and regional buildings.

To define the concept of archetype, it can be interpreted as a conventional and intellectual reference for the typology of buildings (Pieczara, 2019). Often its concepts and rules are transferred to the principles of composing space, which in relation to the surroundings create a context unique to each building. Thus, in this case, it constitutes all the characteristic technical and finishing solutions that appear in the region in question.

\subsection{CONTEXTUALISM IN ARCHITECTURE}

Contextualism firstly pays attention to the context, i.e. the physical neighbourhood and the cultural features attributed to it (Schneider-Skalska, 2008; Wijas, 2019). Its roots go back as far as ancient Egypt and later Greece and Rome, when the concept of genius loci (Landscape Architecture Guide, 2007) referred to the "spirit of the place". It has therefore been an instinctively familiar issue for centuries and has affected various fields of art.

Architecture, as a process of creating or rearranging within the existing context, can be seen as a form of conversation between the new and the old. Each smaller or larger project is situated in a predefined and characteristic environment. With the creation of a new entity, a relationship and dialogue are created in the space between them. The environment can often exert an overwhelming pressure on a building. It can both dominate and be dominated. It is said that an integral part of a building and its expression in its surroundings is the space it creates around itself. And it is in this space that the dialogue takes place and it is in this space that its content is most easily found.

Depending on the effect desired by the architect, the content and nature of this communication can be very different. One of Norwegian architectural firms, Snøhetta, 
has the following motto: "Our work strives to enhance our sense of surroundings, identity and relationship to others and the physical spaces we inhabit, whether feral or human-made" (Snøhetta, n.d.a). In their projects, such as Tverrfjellhytta, among others (Snøhetta, n.d.b), a subordination to nature and the surroundings can be seen, where, by combining the essence of the context with minimalist architecture, synergies and relationships are obtained that seem to fit perfectly and flawlessly with the place.

Libeskind has converted old buildings and added distinctive forms to them. In these projects, which can hardly be called "matched with the context" (Studio Libeskind, 2007), the architect is guided by the rule that a building should be expressive, innovative, fitting into contemporary life. Therefore, the architect creates projects with dynamic and "sharp" lines which stand out strongly and contrast with their surroundings.

This interesting approach encourages further discussion and leaves many more or less positive feelings. The context of the surroundings, whether natural or man-made, thus directly affects the viewer and the viewer's feelings.

\section{ELEMENTS OF REGIONAL DIALOGUE}

The concept of a region is connected with considerations about its "essence". As Z. Chojnicki and T. Czyż wrote, "the issues concern the definition, characteristics, cognitive role, etc.". Most of the ambiguities around the concept of a region have their source in the lack of precise terminology and in the impossibility of providing exhaustive answers to important questions (Tinkler, 1973). In the developed context, it is all the more important that the terminology of a region directly refers to the space of Warmia and Mazury. Using it as a research tool, it comes down to outlining the areas where there is characteristic nature and culture (Chojnicki, Czyż, 1992). Both of these factors have direct impact on the creation of buildings typical for this region.

\subsection{NATURE'S MONOLOGUE}

The landscape of Warmia and Mazury, due to its turbulent history, and mainly the period of glaciation, presents a mixture of hills and depressions. Water occurs there in various forms from ponds and lakes to rivers and streams (ill. 1). This creates a very picturesque area of great natural and historical value. The number and area of forests are also impressive. The area of forests amounts to almost 120,000 hectares in Mazury alone (Ośrodek Skowronki, n.d.).

Marshes and mires are also characteristic elements of this region. The process of their creation is connected with the natural life cycle of lakes, consisting in the shallowing of a body of water, as a result of which swamps and marshy areas are created (Jezioro.com.pl. Twój informator turystyczno-przyrodniczy, n.d.). These areas are valuable for their diversity 


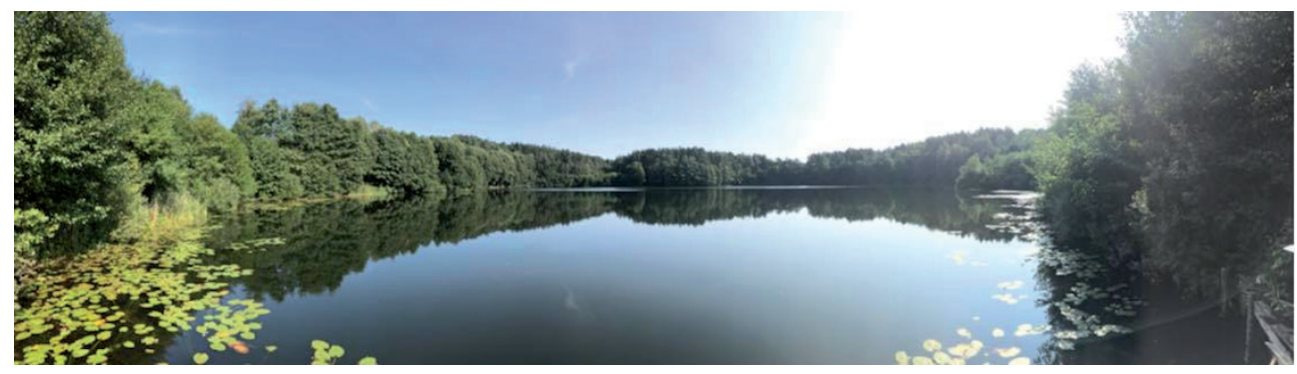

III. 1. View of Lake Czarne, Świerkocin. Photo by author

of species as well as for the long time of their formation. It is therefore important to protect them in the form of nature reserves.

The natural values attracted early settlers to this area, who established their settlements already in pre-Teutonic times (Białuński, 2019).

\subsection{STIGMA OF HISTORY}

The existing architecture in Warmia and Mazury has been significantly affected by the history of this region. An additional element that plays an important role here is nature. It creates environmental conditions which in turn determine the method and technology of construction.

A continental glacier, which was here 14,000 years ago, is responsible for the characteristic topography and numerous hollows in the earth's surface (Lamparski, n.d.). It left behind valleys which, later filled with water, created water reservoirs of various shapes (ill. 2). Fertile soils deposited by ice sheets helped the nature to flourish. Long after the end of the glaciation (11.7 thousand years B.C.), during the beginning of the Holocene era (Marks, 2016), the first settlers slowly began to arrive, which is evidenced by numerous archaeological findings in the area of the village. The oldest of them date back even to the Neolithic period (5200-1900 BC) (Csáky, Zaborowska, Bugaj, 1998).

Culturally, Warmia has more Polish character as it remained within the Polish borders between 1466 and 1772. The territory of Mazury belonged to the Teutonic Knights for a long time and had the form of a Polish fiefdom. As a result, it was officially subordinated to the Duchy of Prussia and therefore significant differences in architecture and culture can be seen there $^{1}$. The first partition of Poland incorporated the area of Warmia into the Prussian state, excluding these lands from Polish influence. German language was gradually introduced in schools in order to unify the province of East Prussia with the rest of the Kingdom.

1 https://sites.google.com/site/regionwarminskomazurski/geologia/polozenie/ciekawostki-o-regionie/historia-regionu (access: 14.12.2020). 


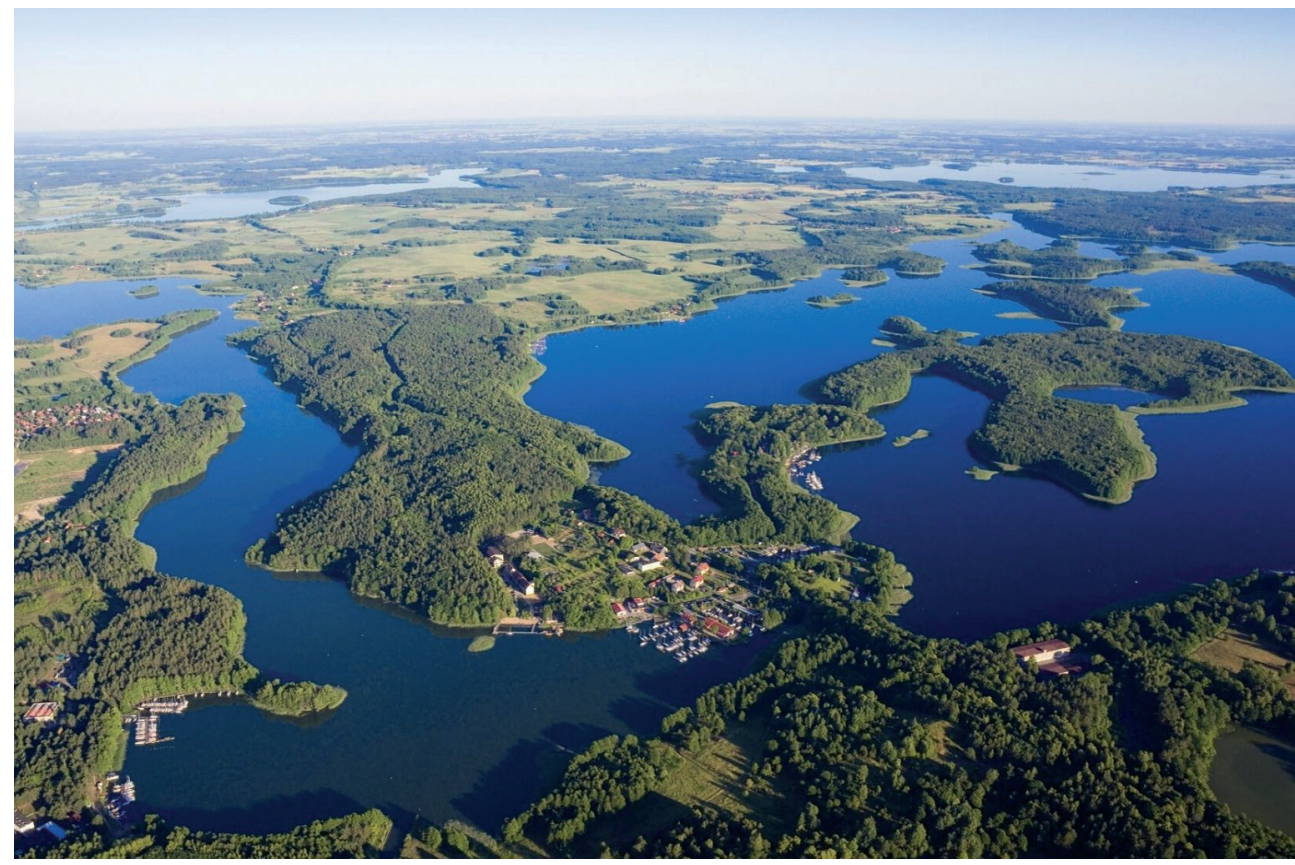

III. 2. Landscape of lakes in Warmia and Mazury (Janz, 2020)

This situation lasted until the outbreak of the First World War in 1914. Unfortunately, as a result of war operations, many cities (among others Ełk and Olsztynek) and villages were destroyed. During the Second World War, this region, due to its links with German culture, was initially only a back-up for the eastern front, but later developments brought similar results to the war between the Entente Powers and the Central Powers less than 21 years earlier.

It is worthwhile to mention that in the $21^{\text {st }}$ century, the differences between the landscape of Warmia and Mazury are gradually blurring, mainly as a result of mass resettlement and cultural change. The marginalisation of tradition is also progressing. Religion is no longer as important as it used to be, it does not actually impose any social requirements, which is why nowadays traditions are rarely continued and in most cases they are only a sign of the past. As M. Wijas presents it in her doctoral dissertation: "fashion becomes more and more important in architecture and new trends are blindly followed, the context of the place is often forgotten and its impact on the process of creating a building and space and high quality of architecture is neglected" (Wijas, 2019). Nevertheless, although the areas of Warmia and Mazury are adjacent to each other, they still differ. The main reason for the existing differences in culture and tradition is religion. The Warmians, geographically closer to the Vistula and the centre of the country, have always been Catholic. The Mazurians, on the other hand, are more closely 
related to Protestant beliefs (Zalewska, 2013). Roadside shrines make it easier for tourists to distinguish between these lands because they occur only in Warmia (Skrago, 2017).

In the architectural context, it is worth noting that all differences also result mainly from the distinctive nature of these two religions. This can be briefly described by a preference for ornamentation. Catholicism is fond of numerous details, ornaments and decorations. Protestantism, on the other hand, prefers simplicity. This principle can be applied to many areas of culture, such as folk costumes. Thus, it may seem that the region of Mazury is much poorer than the region of Warmia, which is usually a very mistaken perception (Zalewska, 2013).

\subsection{TRADITIONAL ARCHITECTURE}

Buildings characteristic for this region can be seen in the Museum of Folk Architecture the Ethnographic Park in Olsztynek. There are numerous examples of faithfully reconstructed cottages, mills, farm buildings, barns and many other structures. These buildings have been constructed using traditional technology and materials in order to preserve the character of the buildings in this region. In addition, they have been placed at a walking distance from each other, which has made it possible to concentrate in a small area examples of buildings that are actually scattered all over the voivodeship (Fotopolska, 2012).

\subsubsection{TRADITIONAL SOLUTIONS}

\section{Prussian wall}

The use of the so-called Prussian wall was characteristic for this area. It is a wall where gaps between the wooden structure are filled with brick. Those filled gaps were then plastered and whitewashed with lime. In his publication Folk Architecture in Poland, Marian Pokropek justifies its popularity with legal regulations of the Prussian government in the $19^{\text {th }}$ century (Prokopek, 1976). The spread of this technology was undoubtedly also affected by the wide availability of building materials.

\section{Foundations}

In the local and traditional style of building, foundations were usually made of fieldstone. It is also frequent, especially in the case of larger buildings, that they were pulled above the ground level and constituted the load-bearing structure of ground floor walls (ill. 3). They were then plastered in white, complementing the appearance of the façade in terms of colour.

\section{Structure}

The ground floor was also sometimes built of wooden logs connected with the use of dovetail technique. The walls were often covered with weatherboards, frequently creating interesting patterns on the walls. 


\section{Roofs}

Gable roofs are also characteristic elements of the local architecture (ill. 3). Reed, straw or shingles were most often used for shaping the roof slope. Later, these materials were replaced by orange roof tiles which, due to the wide area and time range of their use, also fit into the typology of the present archetype (Fotopolska, 2012). The reason for their presence is the Prussian government's ban on using thatch in the $19^{\text {th }}$ century for fire safety reasons (Olszak, 2008).

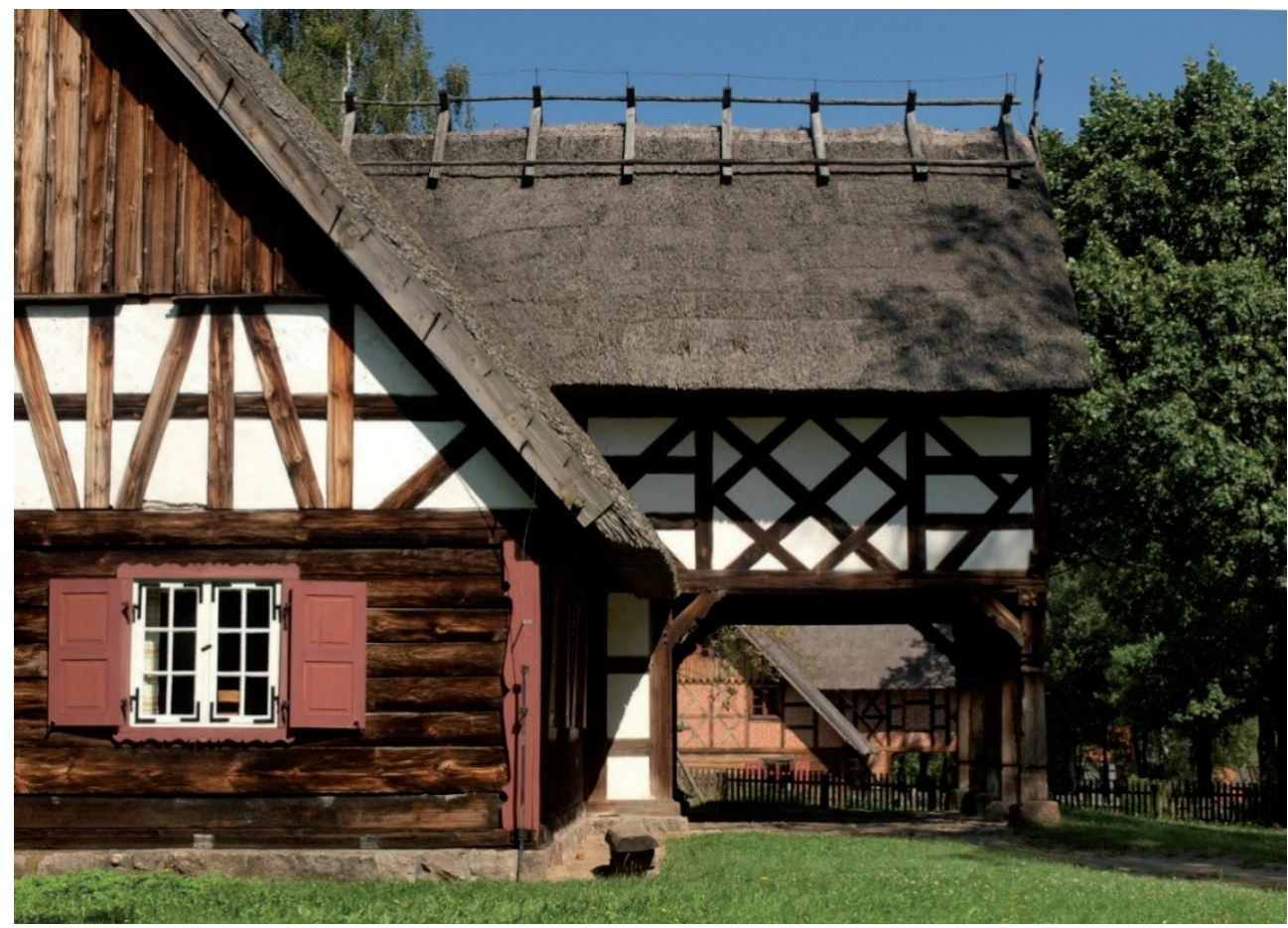

III. 3. Granary in the farm complex in Skandawa (Fotopolska, 2012)

\subsubsection{SPATIAL PATTERNS}

\section{Arcaded house}

The light timber structure of the houses allowed for unusual technical solutions already a long time ago. Among other things, it made it possible to pull back part of the ground floor of the gable wall, which created a characteristic arcade. The ceiling protruding in this way was supported by decorative pillars, creating a porch. They were always added to the longer wall of the building, as the main entrance was located there (ill. 4). The procedure of pulling back the wall was repeated also for the longitudinal walls of farm buildings, forming a roof before the entrance zone (ill. 5). 


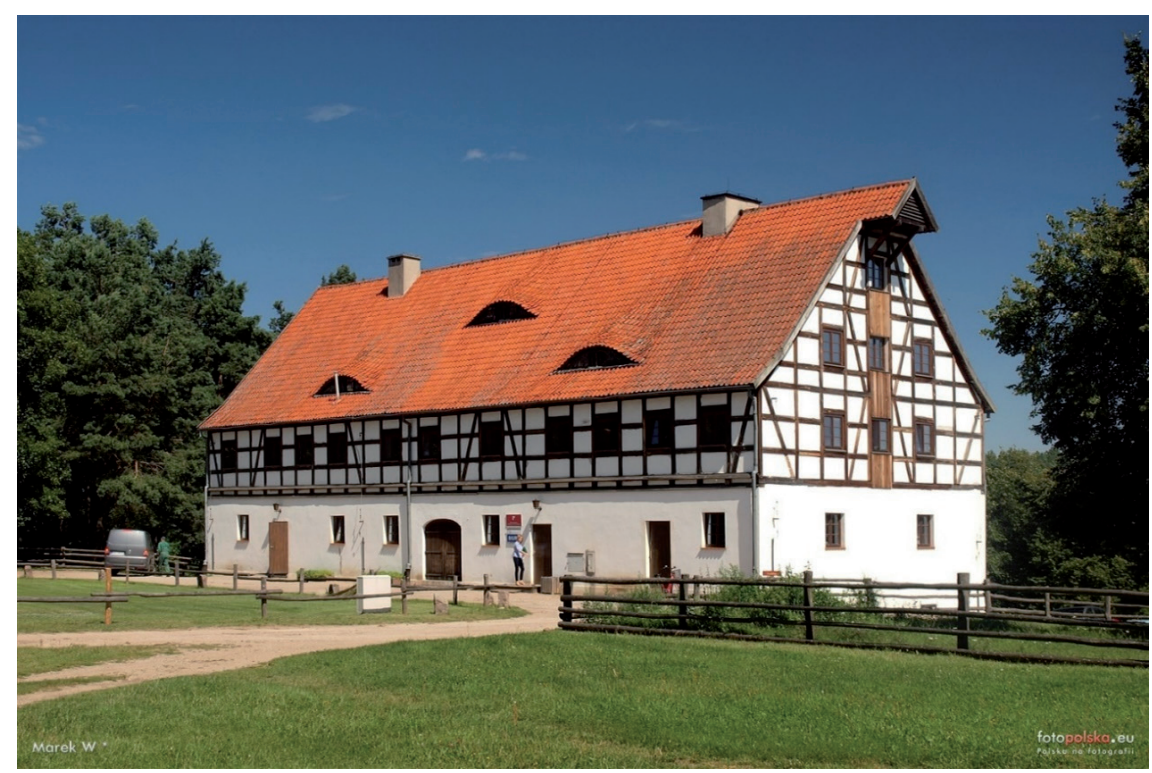

III. 4. Cottage in the village of Burdajny (Fotopolska, 2012)

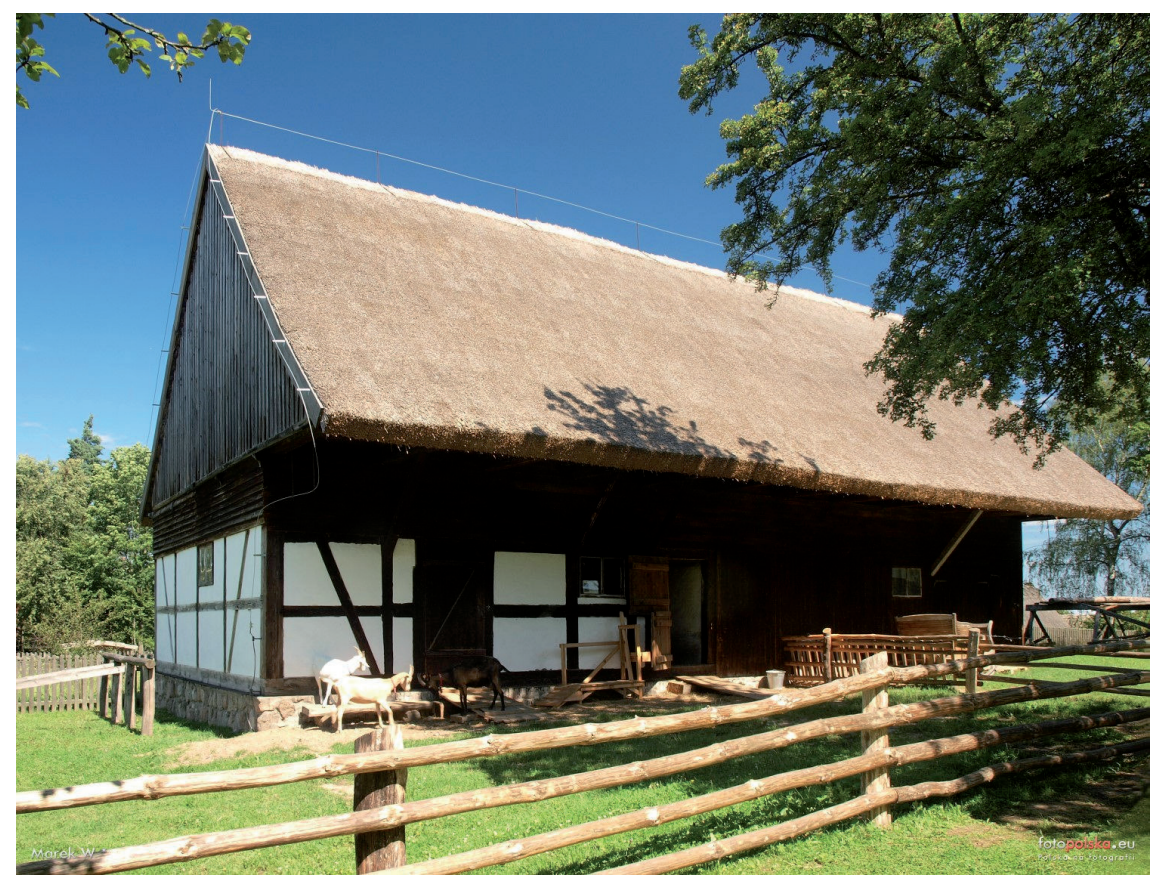

III. 5. Farm building in the village of Kwietniewo (Fotopolska, 2012) 


\section{Gardens}

The commitment of the Warmians and Mazurians to nature is evidenced by their gardens. Usually, there were two of them: the first one - representative flower garden at the main entrance, it had such plants as mallow, jasmine, lilac bushes; the second one - vegetable garden, it was used for fruit and vegetable production. In addition, houses were surrounded by vegetation in the form of tall trees - lime trees, maples, birches. They strengthened the connection with nature, but above all, acted as a primary lightning conductor for the house.

\section{Location}

While analysing the local buildings, one gets the impression of thematic consistency and the existing pattern widespread in the region. Older peasant cottages were usually located parallel to the access road. Two or three structures were built on the land plot. Their functions were related to the character of life in the village. In addition to the residential building, a barn was built which was often extended with utility rooms. Richer farms can be recognised by the greater number of buildings on the land plot. In these cases, stables and barns were built separately as farm buildings (Olszak, 2008) - ill. 5.

\subsection{DISCUSSION}

The impression is that the architecture harmonises with the character of this region. Each building enriches the landscape by introducing contrasting colour in the form of orange roofs or white façade finishes. This adds charm to the existing unusual landscape by tempering the wild and initially picturesque composition of lakes and forests with orderly structures. This contrast in form diversifies the views, giving them a unique character (ills. 6 and 7). Nowadays, the preservation of tradition is influenced by numerous local zoning plans which regulate the possibilities of construction in the region. Unfortunately, building methods changed mainly after the Second World War due to the resettlement of native population (Wysocki, 2003: 66). Gradually, as a result of applicable provisions of law, the original character of the buildings is being restored, along with the preservation of cultural tradition.

\section{CONCLUSIONS}

The reference to the natural and historical context is valuable and worthy of further practice. It prevents the universalisation of architecture. Every work of art has its unique context which is its advantage and should be used - "when we forget about it and design a building completely disconnected from the surroundings, we get a sentence composed of random words or one in which one word definitely does not fit with the rest" (Wrana, Fitta, 2012: 5). 


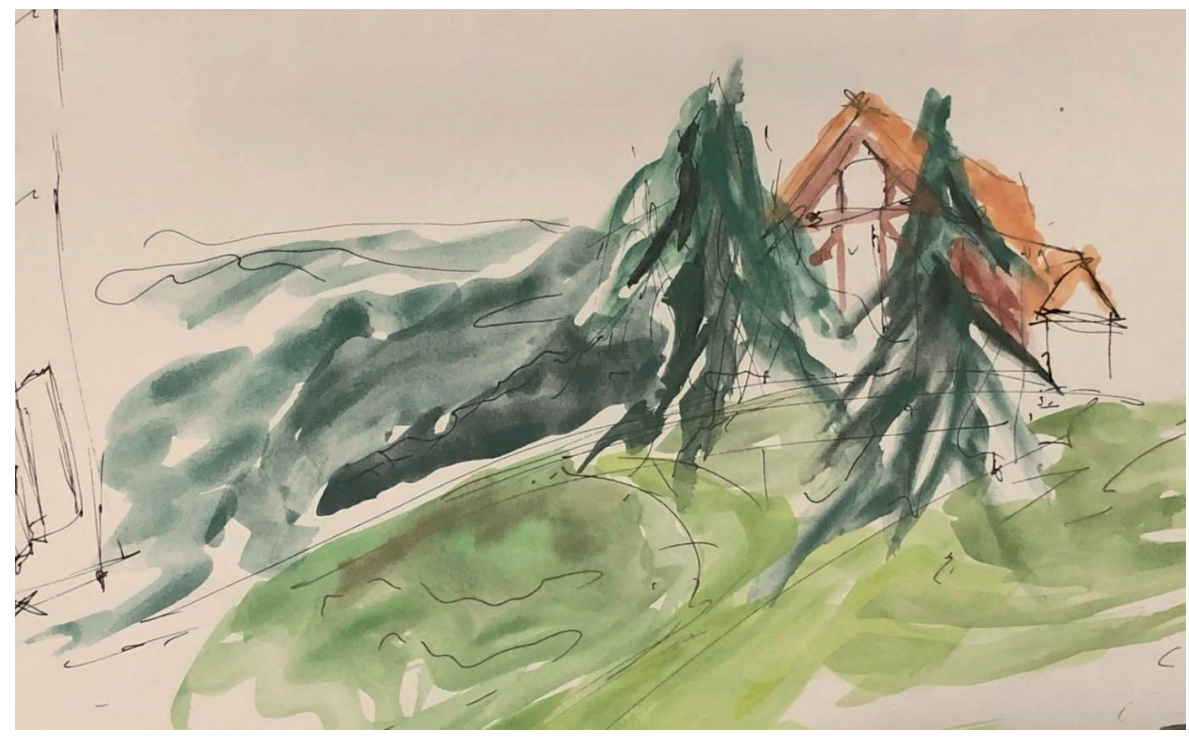

III. 6. Watercolour showing a combination of architecture and greenery in the landscape of Mazury. Drawing by author

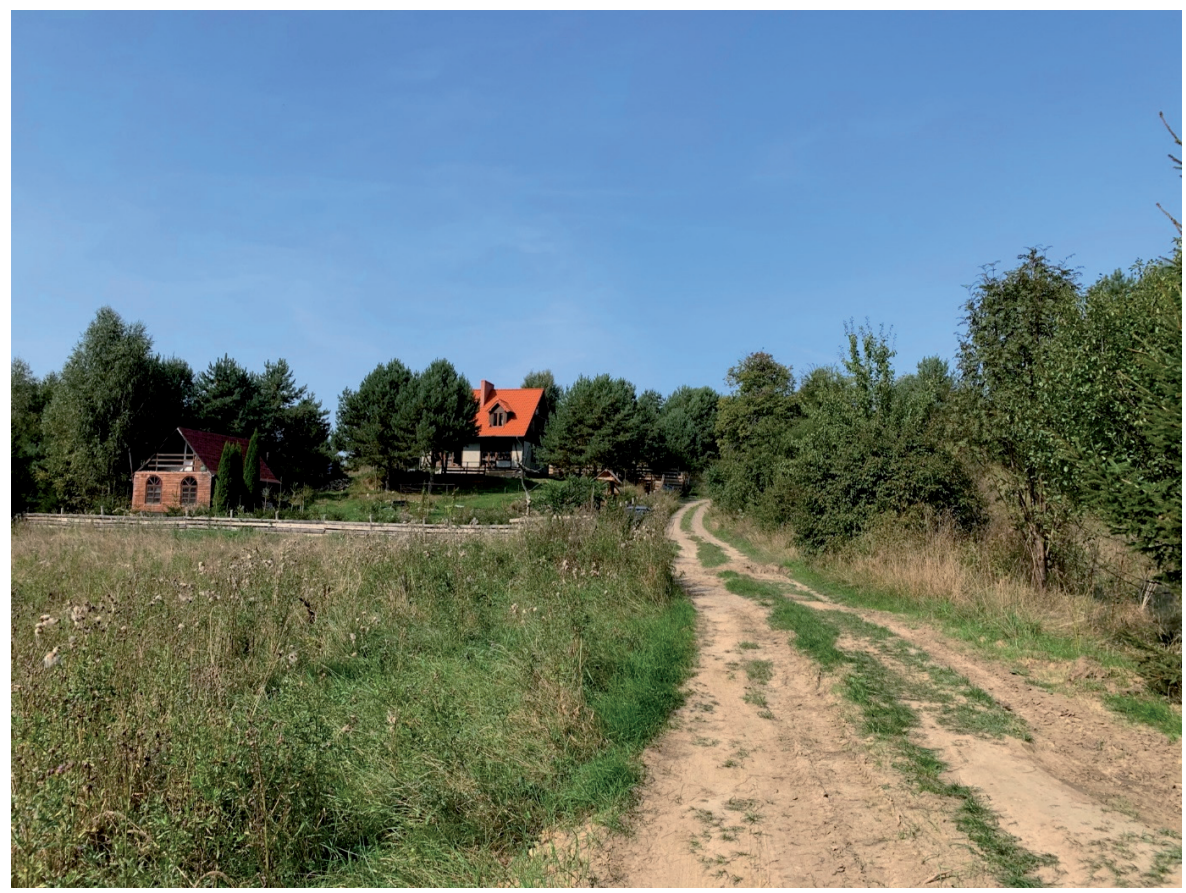

III. 7. View of landscape containing the archetype of Warmia and Mazury. Photo by author 
In Warmia and Mazury, it is easy to see the important role of linking a building with its existing surroundings. The main potential of this region is therefore not only its history, but also its unique style. These aspects create a unique appearance for this region. They have significant impact on the crystallisation of the archetype as an element determining the characteristic appearance of the buildings in this region. Buildings were often constructed using local materials, which facilitated construction and expedited the building process. This fact reinforces the feeling of a harmonious relationship between the residential buildings and nature.

The ethnographic character of this region has changed many times over the centuries due to its turbulent history. This is reflected in the diversity and character of the archetype. The resulting buildings relate to the existing environment, interacting with it on many levels. The key role in the dialogue between the architecture and its surroundings is played by the natural, historical and cultural context. This relationship with the surroundings has significant impact on the perception of regional architecture.

Designing and building in harmony with the region's nature has therefore numerous advantages and is worthy of further practice. Not only does it help to reflect the mentality of the local people at a given time, but also, due to the longevity of the buildings, it refers back to traditions from centuries ago. Thus, local buildings are a kind of museum and they are the fount of knowledge about culture, inhabitants, nature, religion and in addition they bring a unique style.

\section{REFERENCES}

Białuński, G. (2019). Zarys dziejów osadnictwa na Mazurach. Echa Przeszłości, 1(20), 335-336. Csáky, D., Zaborowska, H., Bugaj, M. (red.). (1998). Informator Archeologiczny. Warszawa: Krajowy Ośrodek Badań i Dokumentacji Zabytków.

Chojnicki, Z., Czyż, T. (1992). Region - regionalizacja - regionalizm, Ruch Prawniczy, Ekonomiczny i Socjologiczny, 54(2), 1-18.

Janz, J. (2020). Gdzie na Mazury? Podpowiadamy najlepsze miejsca w krainie jezior!. Retrieved from https://www.travelplanet.pl/blog/gdzie-na-mazury-podpowiadamy-najlepsze-miejsca-na-mazurach/ (access: 14.12.2020).

Jasiński, K. (1978). Utrata Gdańska przez państwo polskie. In: E. Cieślak (ed.), Historia Gdańska. Vol. 1: Do roku 1454 (p. 324). Gdańsk: Wydawnictwo Morskie.

Jezioro.com.pl. Twój informator turystyczno-przyrodniczy. (n.d.). Bagna i torfowiska. Retrieved from https://www.jezioro.com.pl/przyroda/index/index/view/bagna (access: 29.04.2021). Lamparski, S. (n.d.). Mazury jakich nie znacie. Retrieved from http://www.zycieaklimat.edu. $\mathrm{pl} /$ Mazury (access: 14.12.2020). 
Landscape Architecture Guide. (2007). 14.1 Birth of the Genius Loci. Retrieved from https:// web.archive.org/web/20071023180846/http://www.gardenvisit.com/landscape/architecture/14.1-genius-loci.htm (access: 27.02.2021).

Marks, L. (2016). Zmiany klimatu w holocenie. Przeglqqd Geologiczny, 1(64), 59-65.

Fotopolska. (2012). Muzeum Budownictwa Ludowego. Retrieved from https://fotopolska.eu/ Olsztynek/b3725,Muzeum_Budownictwa_Ludowego_-_Park_Etnograficzny.html (access: 24.04.2021).

Olszak, P. (2008). Architektura tradycyjna - Mazury. Retrieved from https://witrynawiejska. org.pl/dziedzictwo-kulturowe/krajobraz-architektura/item/27287-architektura-tradycyjna-mazury (access: 24.04.2021).

Ośrodek Skowronki. (n.d.). Mazury. Retrieved from https://osrodekskowronki.pl/mazury (access: 16.12.2020).

Pieczara, M. (2019). Archetypes in contemporary architecture. Technical Transactions, 4, 71-84.

Prokopek, M. (1976). Budownictwo ludowe w Polsce. Warszawa: Ludowa Spółdzielnia Wydawnicza.

Schneider-Skalska, G. (2008). Dzieło architektoniczne zawsze w kontekście. Czasopismo Techniczne, 6-A(105), 153-157.

Skrago, A. (2017). Warmia, czy Mazury - jak odróżnić. To nie takie trudne. Retrieved from https://radioolsztyn.pl/warmia-czy-mazury-jak-odroznic-to-nie-takie- trudne/01348106 (access: 14.12.2020).

Snøhetta. (n.d.a). Snøhetta is a place nobody is from, but anyone can go to. Retrieved from https://snohetta.com/about (access: 01.03.2021).

Snøhetta. (n.d.b). Tverrfjellhytta, Norwegian Wild Reindeer Pavilion. Retrieved from https:// snohetta.com/projects/2-tverrfjellhytta-norwegian-wild-reindeer-pavilion (access: 01.03.2021).

Studio Libeskind. (2007). Royal Ontario Museum. Retrieved from https://libeskind.com/work/ royal-ontario-museum/ (access: 01.03.2021).

Tinkler, K.J. (1973). A theory of the region. The East African Geographical Review, 11.

Wijas, M. (2019). Kontekst w polskiej architekturze XXI wieku. Wybrane przykłady (Thesis). Kraków: Politechnika Krakowska im. Tadeusza Kościuszki.

Wrana, J., Fitta, A. (2012). Architektura a kontekst miejsca. Budownictwo i Architektura, 11.

Wysocki, J. (2003). Architektura wiejska w cieniu tandetnej nowoczesności. In: I. Liżewska, W. Knercer (ed.), Zachowane - ocalone? O krajobrazie kulturowym i sposobach jego ksztattowania (p. 66). Olsztyn: Wydawnictwo Stowarzyszenia Wspólnoty Kulturowej "Borussia”. Zalewska, B. (2013). Święta Warmia \& Cudne Mazury - co je łq̨czy, a co dzieli?. Retrieved from http://rentyny.net/aktualnosci/swieta-warmia-cudne-mazury-laczy-dzieli/ (access: 14.12.2020).

https://sites.google.com/site/regionwarminskomazurski/geologia/polozenie/c'ekawostki-o-regionie/historia-regionu (access: 14.12.2020).

ADRES BIBLIOGRAFICZNY ARTYKUŁU: Sobol, P. (2021). Contextualism of architecture in Warmiaand Mazury, Przestrzeń/Urbanistyka/ Architektura, 1, s. 101-112. 